\title{
Large Unit Red Cell Cryopreservation with Hydroxyethyl Starch ${ }^{3}$
}

\author{
E. D. ALLEN, L. WEATHERBEE, H. H. SPENCER, S. M. LINDENAUER, \\ AND P. A. PERMOAD \\ Medical Research, Veterans Administration Hospital and University of Michigan \\ Medical Center, Ann Arbor, Michigan 48105
}

Red blood cells can be preserved by freezing using either intra- or extracellular agents. The most common intracellular agent, glycerol, is currently employed in general use and provides clinically acceptable red cells following post-thaw washing (13).

Extracellular agents do not enter the cell during freezing. Therefore, red cells preserved with these agents may be administered without post-thaw processing depending on the agent used and the cell preservation obtained. For example, polyvinylpyrvolidone (PVP) and dextran received considerable attention as extracellular agents but are currently considered unacceptable. PVP yields good cell preservation but the molecular weight which affords the best cryopreservation is retained for long periods in the reticuloendothelial system (12). Dextran is unacceptable because it does not yield adequate cell preservation. Hydroxyethyl starch (HES) possesses many of the characteristics required of an acceptable extracellular cryoprotective agent since it yields high cell recoveries and is nonantigenic (7) and nontoxic $(3,10)$. A high molecular weight HES is currently in use as a plasma expander.

Red cell cryopreservation utilizing HES and other extracellular agents requires

Received October 24, 1975.

${ }^{1}$ Supported in part by Office of Naval Research, Department of the Navy (Contract No. NAonr8-75). faster freezing and thawing rates than does cryopreservation with intracellular agents such as glycerol. In general, this means freezing in liquid nitrogen and thawing in high temperature water baths, incorporating agitation of the unit at both points. It would be advantageous if cells frozen with HES as the cryopreservative could be administered directly after thawing. This article describes results of freezing full units of red cells with HES as the cryoprotective agent.

\section{MATERIALS AND METHODS}

Full units of whole blood (2-5 days old, collected in CPD) were centrifuged at 3000 rpm for $15 \mathrm{~min}$. After centrifugation, supernatant plasma and buffy coat were removed. In experiments using "washed cells" the packed red cells following centrifugation were mixed with an equal volume of $0.9 \% \mathrm{NaCl}$ and the centrifugation and removal of supernatant solution were repeated two additional times.

The starch used in all experiments was a $40 \%$ aqueous solution containing $0.9 \%$ $\mathrm{NaCl}$ prepared from powder (Lot No. P1P005, McGaw Laboratories, Glendale, Calif.). The final concentration of starch in the freezing mixture was $14 \%$ obtained by adding 35 parts of the $40 \%$ starch solution to 65 parts of the red cell mixture. In order to obtain a hematocrit near $40 \%$, the unwashed packed red cells or the $0.9 \% \mathrm{NaCl}$ washed red cells were diluted with plasma 
or $0.9 \mathrm{NaCl}$, respectively, before addition of the $40 \%$ starch.

Freezing mixtures $(385-400 \mathrm{ml})$ were frozen and thawed in Hemoflex bags (Style 7450-2, Union Carbide Corp.) placed in an aluminum holder. The aluminum holder containing the blood bag was kept at $4^{\circ} \mathrm{C}$ for 1-2 $\mathrm{hr}$ before freezing. Freezing was done by imnersing in liquid nitrogen and agitating at $200 \mathrm{cpm}$ for $1 \mathrm{~min}$ followed by $150 \mathrm{cpm}$ for an additional minute using a Linde BP2 blood processing unit. This twostep method of agitation was found effective in reducing the amount of Hemoflex bag breakage (evidenced during thaw). After freezing, the bag was stored in its holder in liquid nitrogen vapor $\left(-140^{\circ} \mathrm{C}\right)$ until thawed (usually 16-24 hr). Thawing was done by immersion of the holder and bag in water $\left(47-49^{\circ} \mathrm{C}\right)$ using the Linde machine at $170 \mathrm{cpm}$. The units were removed from the water bath when the freezing mixture was completely thawed and had reached a temperature of $5-15^{\circ} \mathrm{C}$ (usually $60-70 \mathrm{sec}$ ).

The parameters used to examine the red cells before and after freezing included cell recovery, saline stability, and supernatant hemoglobin which have been previously described (14). Determination of red cell ATP level was done enzymatically by measuring the decrease in optical density of DPNH undergoing oxidation. The reaction which involves two steps utilizes 3-PGA and DPNH as substrates and phosphoglyceric phosphokinase and glyeraldehyde phosphate dehydrogenase as enzymes. The method is not specific for ATP and will measure other nucleoside triphosphates if present. Determination of 2,3-DPG was also done enzymatically by measuring changes of DPNH oxidation. The reaction involves three steps and utilizes ATP and DPNH as substrates and 2,3-DPG phosphatase, phosphoglycerate kinase, and glyceraldehyde phosphate dehydrogenase as enzymes. Both ATP and 2,3-DPG determinations were conducted using commercially
TABLE 1

Examination of Large Units of Red Cells Frozen with $14 \%$ Hydroxyethyl Starch ${ }^{a}$

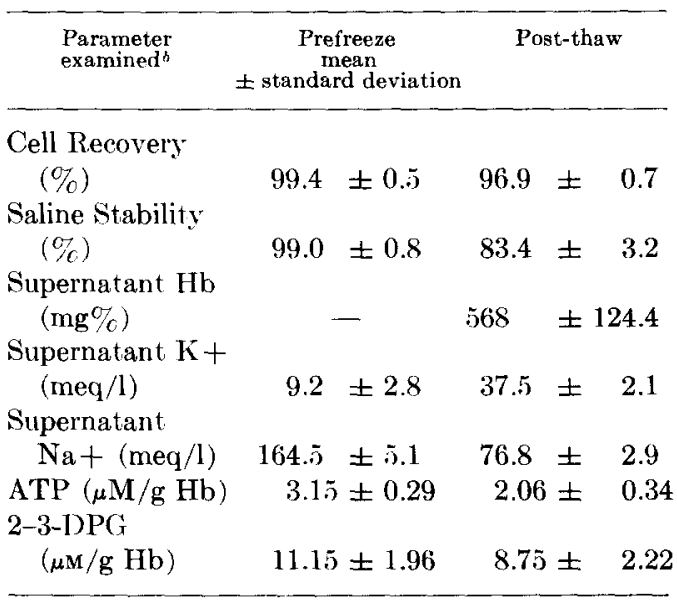

" Volume of freezing mixture $385-400 \mathrm{ml}$; red cell hematocrit near $40 \% \quad(38-44)$; plasma present in freezing mixture.

${ }^{b} N=28$.

available kits (Sigma Chemical Corp., St. Louis, Missouri).

Red cells examined by electron microscopy were fixed in a combination of glutaraldehyde and paraformaldehyde (4). Following fixation ( $1.5 \mathrm{hr}$, room temperature) the cells were washed in $0.1 \mathrm{M}$ sodium cacodylate, $\mathrm{pH} 7.4$ and postfixed in $1 \%$ osmium tetroxide in $0.1 \mathrm{M}$ sodium cacodylate $\left(1 \mathrm{hr}, 4^{\circ} \mathrm{C}\right)$. After alcoholic dehydration the cells were transferred to propylene oxide and embedded in Epon according to Luft (6). Silver-gray sections were cut on a Sorvall MT-2 microtome and stained with $2 \%$ uranyl acetate and lead citrate (11). Sections were examined and photographed with a Hitachi 11a electron microscope operated at $75 \mathrm{kV}$.

\section{RESULTS}

\section{Large Unit Freezing}

The results of freezing large units (385$400 \mathrm{ml}$ final mixture) of red cells with hydroxyethyl starch (HES) are summarized in Table 1. Cell recoveries are 97\% (96.9 $\pm 0.7)$ saline stabilities above $80 \% \quad(83.4$ 
TABLE 2

Examination of Large Units of Red Cells Frozen with 14\% Hydroxyethyl Starch 24 and $48 \mathrm{Hr}$ after Thaw ${ }^{a}$

\begin{tabular}{|c|c|c|c|c|c|c|}
\hline \multirow[t]{2}{*}{ Parameter examined $b$} & Prefreeze & Thaw & \multicolumn{4}{|c|}{ Post-thaw } \\
\hline & \multicolumn{2}{|c|}{ Mean standard deviation } & & $24 \mathrm{hr}$ & & $48 \mathrm{hr}$ \\
\hline Cell Recovery (\%) & $99.6 \pm 0.3$ & $97.2 \pm 0.4$ & 96.7 & \pm & 0.54 & $96.3 \pm 0.7$ \\
\hline Saline Stability $(\%)$ & $99.2 \pm 0.6$ & $83.1 \pm 3.4$ & 81.5 & \pm & 2.9 & \pm 2.4 \\
\hline Supernatant $\mathrm{Hb}(\mathrm{mg} \%)$ & - & $530 \pm 82.8$ & 622 & \pm 10 & 01.6 & \pm 96.4 \\
\hline Supernatant $\mathrm{K}+(\mathrm{meq} / \mathrm{l})$ & $9.3 \pm 3.0$ & $37.6 \pm 1.9$ & 38.6 & \pm & 2.1 & $39.2 \pm 1.7$ \\
\hline Supernatant $\mathrm{Na}+(\mathrm{meq} / \mathrm{l})$ & $164.1 \pm 5.5$ & $77.5 \pm 2.8$ & 77.4 & \pm & 3.4 & $77.2 \pm 3.8$ \\
\hline $\operatorname{ATP}(\mu \mathrm{M} / \mathrm{g} \mathrm{Hb})$ & $3.16 \pm 0.38$ & $2.08 \pm 0.34$ & & $9 \pm$ & 0.65 & $2.04 \pm 0.51$ \\
\hline $2-3 \mathrm{DPG}(\mu \mathrm{M} / \mathrm{g} \mathrm{Hb})$ & $11.42 \pm 1.80$ & $8.89 \pm 2.30$ & 7.32 & $2 \pm$ & 2.54 & $\tilde{5} .24 \pm 2.40$ \\
\hline
\end{tabular}

${ }^{a}$ Red cell hematocrit of freezing mixture near $40 \%$ (39-44), total volume of freezing mixture 385-400 $\mathrm{ml}$, units stored at $4^{\circ} \mathrm{C}$ following thaw.

${ }^{b} N=22$.

$\pm 3.2)$ and levels of supernatant hemoglobin at $570 \mathrm{mg} \%(568 \pm 124)$. Potassium leaves the cells during a freeze-thaw cycle increasing in the external solution from $9.2 \mathrm{meq} / 1$ in the prefreeze blood to $37.5 \mathrm{meq} / \mathrm{l}$ al thaw. ATP and 2,3-DPG levels drop approximately 30 and $20 \%$, respectively, when compared to the blood as received. Plasma is added to the units of packed cells to ensure a final red cell hematocrit near $40 \%$ (Table 1 ).

Only moderate changes occur after thaw when the cells are stored at $4^{\circ} \mathrm{C}$ (Table 2). After $48 \mathrm{hr}$, the cell recoveries remain near $96 \%$ (96.3 \pm 0.7$)$ with the saline stabilities still above $80 \%(81.1 \pm 2.4)$. The levels of supernatant hemoglobin increase 150 to 700 $\mathrm{mg} \%$; ATP and potassium remain nearly unchanged, and the levels of 2,3-DPG decrease.

We have previously reported that the presence of plasma lowered the saline stability of small units of red cells $(30 \mathrm{ml}$ freezing mixtures) frozen with HES but had no effect on the cell recoveries or levels of supernatant hemoglobin (14). To determine whether a similar effect was observed with large units of red cells under the conditions used here, units were washed with $0.9 \% \mathrm{NaCl}$ to remove plasma. Saline was added to the cells following centrifugation to adjust the hematocrit to near $40 \%$. Compared to the units frozen with unwashed cells (Tables 1 and 2), the various parameters examined at thaw with the prefreeze washed cells are nearly the same (Table 3 ).

TABLE 3

Examination of Large Units of Prefreeze washed Red Cells Frozen with $14 \%$ Hydroxyethyl Starch ${ }^{*}$

\begin{tabular}{|c|c|c|c|c|c|}
\hline \multirow{2}{*}{$\frac{\text { Parameter examined }{ }^{b}}{\text { Cell Recovery }(\%)}$} & Prefreeze ${ }^{c}$ & \multicolumn{2}{|c|}{ Thawc } & \multicolumn{2}{|c|}{$24 \mathrm{Hr}$ post-thaw } \\
\hline & 99.8 & 97.0 & 0.1 & $96.7 \pm$ & 0.8 \\
\hline Saline Stability $(\%)$ & $99.7 \pm 0.3$ & 82.7 & $\pm \quad 3.1$ & $81.5 \pm$ & 3.2 \\
\hline Supernatant Hb (mg\%) & $23.0 \pm 11.9$ & 621 & \pm 129.6 & $674 \pm$ & 74.3 \\
\hline Supernatant $K+(\operatorname{meq} / 1)$ & $0.2 \pm 0.1$ & 33.5 & \pm 3.5 & $35.8 \pm$ & 3.2 \\
\hline Supernatant $\mathrm{Na}+(\mathrm{meq} / \mathbf{l})$ & $156.1 \pm 4.9$ & 71.1 & $\pm \quad 2.6$ & $69.8 \pm$ & 5.7 \\
\hline $\operatorname{ATP}(\mu \mathrm{M} / \mathrm{g} \mathrm{Hb})$ & $3.28 \pm 0.32$ & 2.40 & 0.27 & $1.98 \pm$ & 0.24 \\
\hline $2-3-\mathrm{DPG}(\mu \mathrm{M} / \mathrm{g} \mathrm{Hb})$ & $12.32 \pm 1.14$ & 9.26 & 1.52 & $7.96 \pm$ & 1.38 \\
\hline
\end{tabular}

a Hematocrit of freezing mixture near 40\% (42.5-47); pre-freeze values are taken from cells following 3 saline washes, volume of freezing mixture $=385-400 \mathrm{ml}$.

$N=20$.

c Mean \pm standard deviation. 
Only: the level of supernatant hemoglobin differs appreciably and shows an average increase of almost $100 \mathrm{mg} \%$ in the units washed before freezing. The level of extracellular potassium is lower but may reflect removal from the whole blood by the washing procedure. Examination of the prefreeze washed units $24 \mathrm{hr}$ post-thaw (Table 3 ) indicates that the washed units also change very little when stored at $4^{\circ} \mathrm{C}$.

\section{Electron Microscopy}

To determine whether any ultrastructural changes were apparent in the red cells following a freezing and thawing cycle, thin sections were examined by electron microscopy. Figures 1-2 show portions of red cells in the presence of $14 \%$ HES before freezing. The membranes are intact and continuous along the margin of the cell. Rarely, a small portion of the membrane shows a discontinuity (see arrows Fig. 2) which may represent localized damage to the membrane.

When the cells are fixed immediately following thaw, the membrane of most cells appears similar to those of cells before freezing (Fig. 1). However, a small number of cells in the freezing mixture appear as shown in Fig. 3. The cell membrane is not continuous, but instead shows numerous gaps or regions in which part of the membrane is missing. Cells similar to those shown in Fig. 3 have not been observed before freezing and are believed to show damage acquired during the freeze-thaw cycle.

\section{DISCUSSION}

The methods described for freezing large units of HES-preserved red cells yield units with cell recoveries near $97 \%$ and saline stabilities near $83 \%$. Potassium leaves the cell and raises the extracellular concentration of this ion to $35 \mathrm{meq} / \mathrm{l}$. Examination of the thawed units following storage at $4^{\circ} \mathrm{C}$ for $48 \mathrm{hr}$ revealed essentially no changes in red cells as measured by the various parameters used for their evaluation. The removal of plasma from these large units before freezing does not change the various parameters at thaw. This indicates that under the freezing and thawing conditions used here, prefreeze washing for removal of plasma, leucocytes, etc., could be employed without affecting the cells.

It is fcasiblc to administer these units under certain circumstances, but before they could be used under usual clinical conditions it would be desirable to reduce the level of supernatant hemoglobin and potassium. At present, several options are available for accomplishing this. One method is further manipulation of the freezing and thawing conditions when employing HES. Previous work with small units $(30-40 \mathrm{ml})$ indicates that $98-99 \%$ cell recovery is possible. However, at the present time it is probably not possible to obtain cell recoveries of $100 \%$ and thus eliminate all free hemoglobin at thaw. It is possible, however, that the loss of potassium from the cells (and its exchange with sodium ) may not be prevented by an empirical approach. As suggested by Meryman, the exchange of solutes during the freeze-thaw cycle may be related to the mechanism by which extracellular agents afford protection $(8,9)$. If so, reducing the loss of potassium from the cells during freeze-thaw may also reduce the extent of cell recovery. The exchange of solutes during the freeze-thaw cycle needs further examination.

Optimizing freezing and thawing conditions with hydroxyethyl starch is limited currently by the availability of the starch. All the experiments described here have used HES with a molecular weight of $120,000-150,000$ and a degree of substitution of 0.75 . Freezing experiments comparing this starch with the higher molecular weight plasma expander revealed that the latter does not preserve cells as well (unpublished data). Very little is known about the parameters of HES which affect its cryopreservative ability. We have been un- 

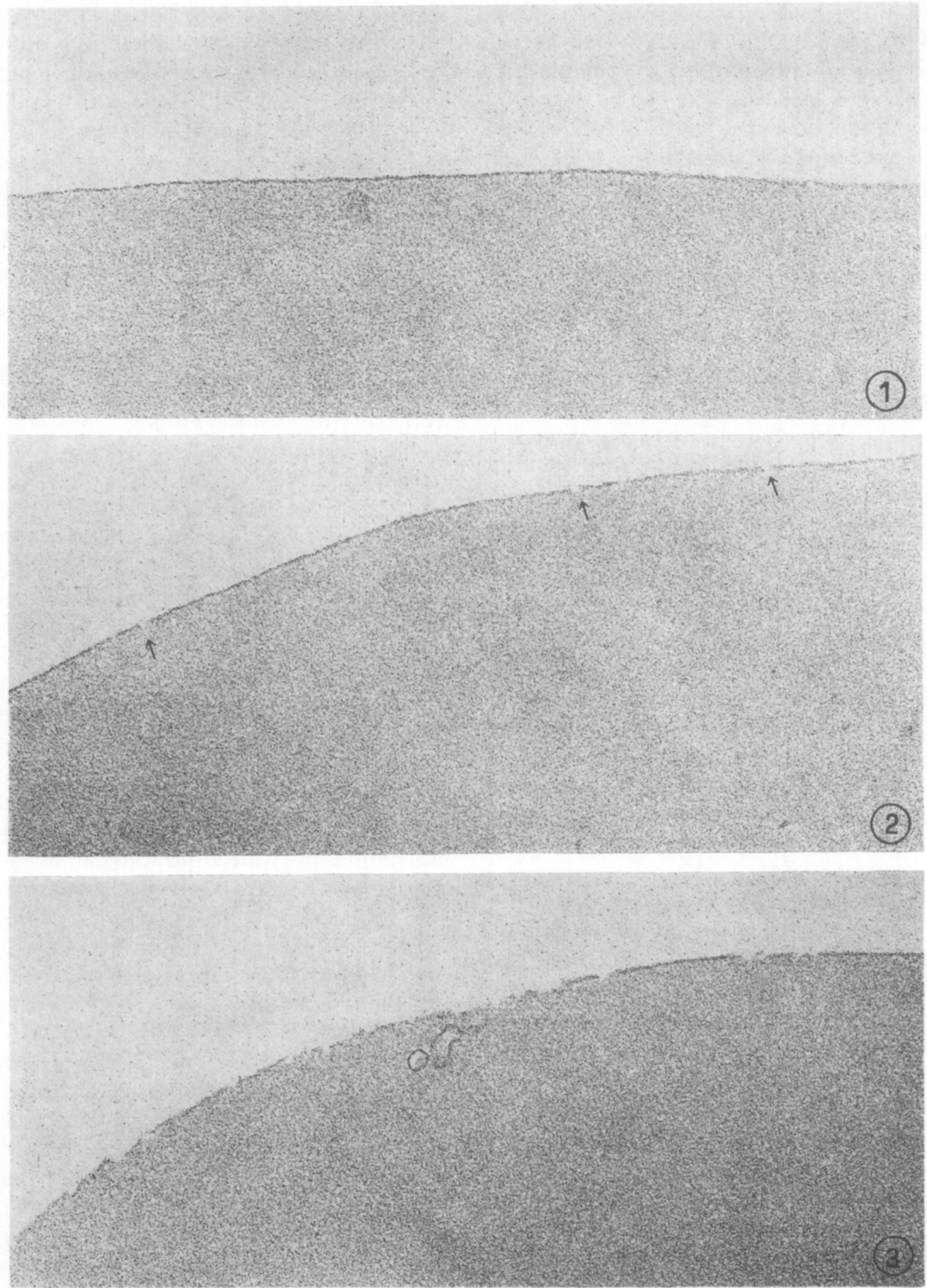

FiG. 1. Portion of unfrozen red cell in the presence of $14 \%$ hydroxyethyl starch showing a continuous cell mcmbranc $\times 78,850$.

FIG. 2, Portion of unfrozen red cell in the presence of $14 \%$ hydroxyethyl starch in which small regions of the cell membrane are missing (arrows) $\times 78,850$.

Fic. 3. Portion of red cell frozen and thawed with $14 \%$ hydroxyethyl starch. Note extensive regions where cell membrane is missing $\times 78,850$. 
able to determine whether starches of different degrees of substitution (DS) affect cryopreservation. Such experiments require chemical characterization of the starch and as Banks et al. have shown two hydroxyethyl starches with the same DS may be very different depending on where the ethylene oxide units are incorporated ( 1 , $2)$. The most suitable molecular weight fraction of HES for cryopreservation is also unknown. The starches are chemically described by two values which indicate the heterogeneity of the polymer. For example, the starch used in these experiments has a weight average molecular weight (MW) of 120,000-150,000 and a weight number molecular weight (MN) of 41,000 . Whether hydroxyethyl starches made from different fractions of amylopectin will vary in cryopreservative ability needs further elaboration. Thus, at present it is not possible to determine whether a particular molecular weight fraction is more effective as a cryopreservative than another. Such unknown factors discourage continued empirical studies on large units of red cells using the "cryoprotective" HES.

An alternative to manipulative changes during freeze and thaw is to accept the $2-3 \%$ cell loss during freeze-thaw and to concentrate on improving the product after thaw. This may be accomplished by a simple wash procedure directed at dilution of the thawed HES-red cell mixture to reduce its viscosity and to remove supernatant hemoglobin and potassium. A procedure describing post-thaw washing red cells frozen with HES (5) and more recent data (unpublished) have shown it is possible to suspend the thawed cells-HES in several buffers without additional cell damage (as expressed by changes in levels of supernatant hemoglobin). However, when the ionic strength of the buffers is gradually reduced, increased damage is observed. Increased levels of supernatant hemoglobin are particularly evident if the cells are suspended in saline or low ionic strength buffers following initial dilution. It is of particular concern to determine whether the increased hemoglobin is the result of additional cell lysis or of cell injury without cell lysis. The latter is envisioned as an intact cell which does not lyse but which possesses membrane damage permitting hemoglobin to leak from the cell.

As shown in this study, a small portion of red cells at thaw show small regions in which the cell membrane is missing. Since the cells were fixed following thaw, it is not possible to determine when damage occurred. Because cells suspended in HES and fixed without freezing and thawing only rarely reveal cells with damaged membranes, it is evident this damage is a result of the freeze-thaw cycle.

Examination of thin sections of the thawed cells has not revealed cells or cell fragments which would indicate completely lysed cells. It is possible that such cells or cell fragments are lost during fixation or dehydration of the samples, and are not present among those cells embedded for thin sectioning. At present, however, it cannot be ruled out that the free hemoglobin in the sample comes from cells which leak hemoglobin but remain intact. If this is the case it means that the $2-3 \%$ cell loss indicated by the determination of the cell recovery is misleading. The value for cell recovery is derived by comparison of optical densities ( $540 \mathrm{mu}$ ) of the supernatant hemoglobin (the amount of free hemoglobin released during freezing and thawing) and the total hemoglobin present (a portion of the thawed sample completely lysed). A correction for the hematocrit is made, and the cell recovery of the sample is determined without knowledge of the actual amount of hemoglobin present in the supernatant or total sample. It assumes all free hemoglobin arises from completely lysed cells. If the free hemoglobin arises from cells which are leaking hemoglobin rather than from those totally lysed, a larger percentage of cells would be involved. If this occurs, it also raises the question of whether those cells which lose hemoglobin become resealed and functional following resealing. The question raised in this paper 
of temporary membrane damage related to the freeze-thaw process merits further investigation. Delineation of the nature of such changes may well hold the clue to basic characteristics necessary in extracellular cryoprotective agents.

\section{SUMMARY}

Full units of red blood cells frozen with $14 \%$ hydroxyethyl starch (HES) yield cell recoveries near $97 \%$ and saline stabilities greater than $80 \%$. Potassium leaves the cells during the freeze-thaw cycle and increases the extracellular concentration of this ion to near $35 \mathrm{meq} / \mathrm{l}$. Unwashed cells (those with plasma present) and saline washed cells yield similar results. Storage of the thawed red cells at $4^{\circ} \mathrm{C}$ for up to $48 \mathrm{hr}$ causes little change in the cells.

Examination by electron microscopy of samples from thawed units reveals some red cells with portions of their membrane missing. We believe this represents damage from the freeze-thaw cycle and also that all free supernatant hemoglobin does not arise from completcly lysed cells.

\section{ACKNOWLEDGMENT}

The authors thank Dr. Fabian J. Lionetti, Center for Blood Research, Boston, for the aluminum holders used in this study.

\section{REFERENCES}

1. Banks, W., Greenwood, C. T., and Muir, D. D. Studies on hydroxyethyl starch. Die Starke 24, 181-187 (1972).

2. Banks, W., Greenwood, C. T., and Muir, D. D. The structure of hydroxyethyl starch. Brit. J. Pharmacol. 47, 172-178 (1973).

3. Gollub, S., Schechter, D. C., Hirose, T., and Bailey, C. P. Use of hydroxyethyl starch solutions in extensive surgical operations. Surg. Gynecol. Obstet. 128, 725-728 (1969).
4. Karnovsky, M. J. A formaldehyde-glutaraldehyde fixative of high osmolarity for use in electron microscopy. J. Cell Biol. 27, 137A138A (1965).

5. Knorpp, C. T., Starkweather, W. H., Spencer, H. H., and Weatherbee, L. The preservation of erythrocytes at liquid nitrogen temperatures with hydroxyethyl starch; the removal of hydroxyethyl starch from erythrocytes after thawing. Cryobiology 8, 511-516 (1971).

6. Luft, J. H. Improvements in epoxy resin embedding methods. J. Biophys. Biochem. Cytol. 9, 409-414 (1961).

7. Maurer, P. H., and Berardinelli, B. Immunologic studies with hydroxyethyl starch (HES), a proposed plasma expander. Transfusion 8, 265-268 (1968).

8. Meryman, H. T., and Hornblower, M. Changes in red cells following rapid freezing with extracellular cryoprotective agents. Cryobiology 9, 262-267 (1972).

9. Meryman, H. T. Freezing injury and its prevention in living cells. Ann. Rev. Biophys. Bioengin. 3, 341-363 (1974).

10. Metcalf, W., Papadopoulos, A., Tufaro, R., and Barth, A. A clinical physiologic study of hydroxethyl starch. Surg. Gynecol. Obstet. 131, 255-267 (1970).

11. Reynolds, E. S. The use of lead citrate at high $\mathrm{pH}$ as an electron-opaque stain in electron microscopy. J. Cell Biol. 17, 208-212 (1963).

12. Robson, D. C. Rapid freezing and thawing techniques using extracellular agents. In "Modern Problems of Blood Preservation" (W. Spielman and S. Seidl, Eds.), pp. 204208. Gustav Fisher Verlag, Stuttgart (1970).

13. Valeri, C. R. Simplification of the methods for adding and removing glycerol during freezepreservation of human red cells with the high or low glycerol methods: Biochemical modifications prior to freezing. Transfusion 15, 195-218 (1975).

14. Weatherbee, L., Allen, E. D., Spencer, H. H., Lindenauer, S. M., and Permoad, P. A. The effect of plasma on hydroxyethyl starch-preserved red cells. Cryobiology 12, 119-122 (1975). 